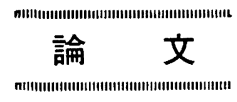

UDC $\quad 621.793 .5: 669.586 .5: 669.15$

\title{
連続溶融亚鉛メッキにおけるドロス生成反応についで
}

\author{
山口洋**.久松敬 弘***

\section{Reaction of Dross Formation in Continuous Galvanizing} \\ Hiroshi Yamaguchi and Yoshihiro Hisamatsu
}

Synopsis:

A study has been carried out on the dross formation in continuous galvanizing in relation to the aluminium content in the bath.

Iron and aluminium concentrations in drosses formed in conventional galvanizing lines are determined. In the laboratory, $\mathrm{Zn}$ alloys containing $0.22 \% \mathrm{~Pb}, 0.13 \sim 0.60 \% \mathrm{Al}$ and $0.066 \sim 0.24 \% \mathrm{Fe}$ are molten in graphite crucibles and held at $465^{\circ} \mathrm{C}$ for $40 \mathrm{hrs}$ before cooling. Using the sectioned ingots, spectroscopic analysis of the portions free from dross and quantitative microscopy analysis of dross compounds are performed.

On the basis of these results, the amount of dross and that of aluminium consumed in the dross formation reaction in conventional processes are estimated. Conclusions derived are as follows:

Drosses contain two compounds, namely $\delta$ and $\mathrm{Fe}_{2} \mathrm{Al}_{5}$.

When the aluminium content in the bath is in the range of $0.09 \sim 0 \cdot 14 \%, \delta$ and $\mathrm{Fe}_{2} \mathrm{Al}_{5}$ can coexist. In this case the higher the aluminium content, the lower the fraction of $\delta$-compound. When the aluminium content is higher than $0 \cdot 15 \%$ the $\delta$-compound can not be found.

The amount of the bottom dross is estimated to decrease rapidly with increasing the aluminium content in the bath up to $0.14 \%$ and becomes negligible above $0.15 \% \mathrm{Al}$. The amount of the top dross, however, increases rapidly with increasing the aluminium content up to $0 \cdot 14 \%$ and decreases gradually above $0 \cdot 15 \% \mathrm{Al}$.

The amount of aluminium consumed in the dross formation reaction is estimated proportional to the amount of iron dissolved from sheets.

(Received Mar. 12, 1973)

\section{1. 緒}

われわれは第 1 報1)，第 2 報2)において，連続溶融亚鉛 メッキにおける鋼板とメッキ浴との間の反応に着目して 検討を行なつてきた. 今回は前報までに検討した鋼板か らメッキ浴中へ溶出した Fe が，その後どのような機構 でドロスとなつてゆくかを明らかにすることにした。こ の目的のため小型ルツボでドロスを生成させて，その結 果を実操業条件に適合させる方法を考えた.

\section{2. ドロスについて}

連続溶融亜鉛メッキ操業におけるドロスには，メッキ 槽の底部に堆積するボトムドロスとメッキ浴面に浮上し てたまるトップドロスとがある.

Photo. 1 と Photo. 2 に実操業ラインで生成したボト ムドロスとトップドロスの顕微鏡写真例を示す. 写真に 見るようにドロスとは金属間化合物とメッキ浴融体との
混合物である.ただし Photo. 2 に見る.らにトップド ロスは，過剩付着亚鉛をふき落すガスワイプ操作により 多量に発生するメッキ浴酸化物と，金属間化合物および $\mathrm{Zn}(\eta)$ の 3 者の混合物からなつている.

Fig. 1 は数社のラインから発生したドロスについて, ドロス中の $\mathrm{Fe}$ と $\mathrm{Al}$ の分析值の過去数年間における半 年ごとの平均值をプロットしたものである. プロットし た点が広い範囲に分布しているのは，汲みとられたド口 ス中の金属間化合物とこれに付着してくる Zn との比率 が場合によりかなり異なるためである．罒からトップド ロスの方がボトムドロスより Al 含量が多いこと, 例外 もあるがドロス中の $\mathrm{Al} / \mathrm{Fe}$ 比はトップドロスで $1 \cdot 0$, ボ トムドロスで 0.33 であることがわかる.

ドロスを構成する金属間化合物は，RENNHACK ${ }^{3)}$ ある

* 昭和 48 年 3 月 12 日受付

**三井金属鉱業 (株) 中央研究所

*** 東京大学工学部金属工学科 工博 


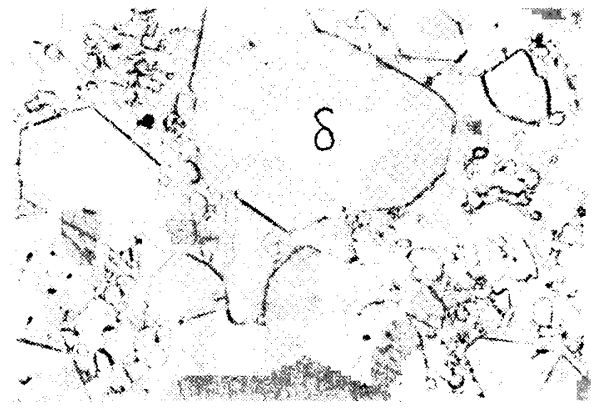

Photo. 1. Bottom dross formed in a conventional galvanizing line. $(\times 100)(4 / 5)$

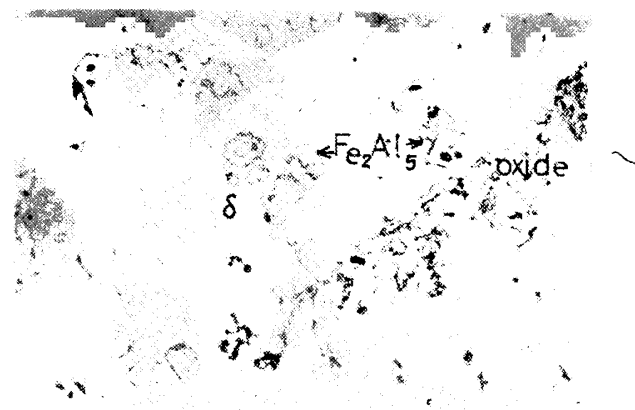

Photo. 2. Top dross formed in a conventional galvanizing line. $(\times 100)(4 / 5)$

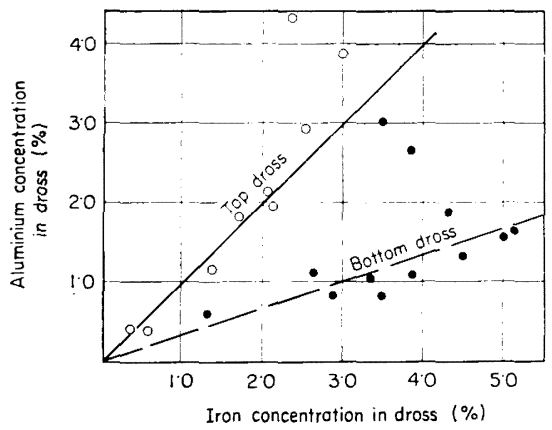

Fig. 1. Plot of iron concentration vs. aluminium concentration in drosses formed in industrial lines.

、は KC̈STER らいよる Zn-Fe-Al 3 元状態虲およびそ つ論文中の組織写真との対比から $\delta\left(\mathrm{Fe} \mathrm{Zn}_{7}\right)$ と $\mathrm{Fe}_{2} \mathrm{Al}_{5}$ 上であると考えられる. 本実験で得られた両化合物の顕 改鏡写真を Photo. 3 と Photo. 5 に示す. なお CAMERON ら5)はメッキ浴中の Al 濃度が $0 \cdot 15 〜 0.30 \%$ のきに 上成するものは $\mathrm{Fe}_{2} \mathrm{Al}_{5}$ 相ではなく $\mathrm{Zn}-\mathrm{Fe}-\mathrm{Al} 3$ 元化合 勿であるとしているが，この点に関しては後に若干の众 寸安行なう.
KÖSTER らの 3 元状態図から, $\delta\left(\mathrm{FeZn}_{7}\right)$ 化合物の $\mathrm{Al}$ 固溶限の高い側の組成はおよそ $10 \% \mathrm{Fe}, 3 \% \mathrm{Al}, 87 \% \mathrm{Zn}$ であり, $\mathrm{Fe}_{2} \mathrm{Al}_{5}$ 化合物の $\mathrm{Zn}$ 固溶限の高い側の組成はお よそ $45 \% \mathrm{Fe}, 43 \% \mathrm{Al}, 12 \% \mathrm{Zn}$ と読夕とれる.各化合物 の $\mathrm{Al} / \mathrm{Fe}$ 比を計算すると $\delta$ では $0.3, \mathrm{Fe}_{2} \mathrm{Al}_{5}$ では $1 \cdot 0$ であり，前述の Fig. 1 に関する検討と一致する. また $\mathrm{FeZn}_{7}$ 化合物の密度は 7.256) であり, $\mathrm{Fe}_{2} \mathrm{Al}_{5}$ 化合物の 密度は $4 \cdot 2^{7)}$ とされている，乙たがってこれらと溶融 $\mathrm{Zn}$ の密度 6.98) とを比較することにより， $\delta$ 化合物が 沈气傾向があること， $\mathrm{Fe}_{2} \mathrm{Al}_{5}$ 化合物が浮上する傾向が 大きいことが理解できる.

\section{3. 実 験 方 法}

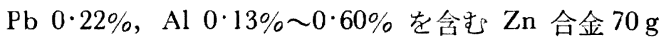
を黑鉛ルツボ中に融解し，これに Fe を，4\% Fe-Zn 母 合金の形で添加してドロスを生成させたＦe を添加す る際は母合金をくだき, 塩化物フラックス処理1)して少 量ずつ浴に添加した. Fe の添加量は $\mathrm{Zn}$ 浴に対して $0.066 \%$ 0. $240 \%$ とし, $\mathrm{Fe}$ 添加後 $465^{\circ} \mathrm{C}$ で $40 \mathrm{hr}$ 静 置してドロスを安定なものとし，冷却凝固させた。イン ゴットを縦方向に 2 つ割りにして断面を研磨した．Feの 添加量は溶融 Znに対し過飽和で, 得られた試料の上部 にはトップドロスが，下部にはボトムドロスが認められ たが，中央部には化合物はほとんどなかつた。この中央 部を分光分析して，化合物を含まない部分の $\mathrm{Al}$ 濃度と $\mathrm{Fe}$ 濃度とを定めた。

顕微鏡観察によりトップドロスおよびボトムドロス中 の金属間化合物の量を計測した，計測方法は鉄鋼中の非 金属介在物測定法における点算法と同梯で，顕溦鏡の接 腿鏡部に格子板をそう入し，視野内の金属間化合物像の 中にある格子点の数を測定する. 測定は格子板内の格子 点の数が 100 個, 顕微鏡の倍染は 200 倍の条件で行なつ た、計测個所はトップドロスとボトムドロスそれぞれに つき横方向に任意に 5 箇所をえらえだ。たとえば，トッ ブドロスについては，インゴット断面の上端から各目盛 板が接縄するように縦方向にずらして，試料中央部にい たり化合物が見当たらなくなるまでくり返し計測すると いう方法を, 横方向 5 箇所につきそれぞれ実施し, 累積 格子点数を求めた：ボトムドロスについても，インゴッ ト下端から計測を開始すること以外まつたく同様であ る.なお，格子点数の測定は $\delta$ 相, $\mathrm{Fe}_{2} \mathrm{Al}_{5}$ 相のそれぞれ につき别個に行なつた：この格子点数は金属間化合物相 の体程浱度に対応し9，試料の寸汒と格子の寸法とから 本实験における計測格子点数 100 は，金属問化合物相が 浴中に0.8体積％存在与ることに相当与る。 


\section{4. 実 験 結 果}

\section{1 ドロスのない部分についての分析結果}

分光分析によって得られた，試料中央のドロスを含ま ない部分の $\mathrm{Fe}$ と $\mathrm{Al}$ の濃度の関係を Fig. 2 に示す.

金属間化合物相の液体 $\mathrm{Zn}$ 相からの分離は非常に時間 がかかるので，冷却時の変化にかかわらずインゴット中 央部バルクの $\mathrm{Al}, \mathrm{Fe}$ 分析值は, $465^{\circ} \mathrm{C}$ において化合物 相と平衡している液体 $\mathrm{Zn}$ 中の $\mathrm{Al}$ 濃度とそれに対応し た Fe 飽和濃度とみなすことができる．この観点から，

Fig. 2 に示された曲線を以後 $\mathrm{Fe}$ 飽和濃度を表わす溶解 度曲線とみなす。なお，PeArCE ${ }^{10)}$ は， Fe 飽和濃度とし て, 0\% Al で 0.04\% (Nathans, 1957), 0.2\% Al で 0.025\% (FrIEBEL, 1961)，4\% Al で 0.0004\% (Friebel ら，1961) を紹介している.

本実験では Fe は飽和濃度以上に添加されているが, $\mathrm{Fe}$ 添加前の $\mathrm{Zn}$ 中の $\mathrm{Al}$ 濃度（全 $\mathrm{Al}$ 濃度と称すること とする）と $\mathrm{Fe}$ 添加後の, ドロスのない部分の $\mathrm{Al}$ 浱度

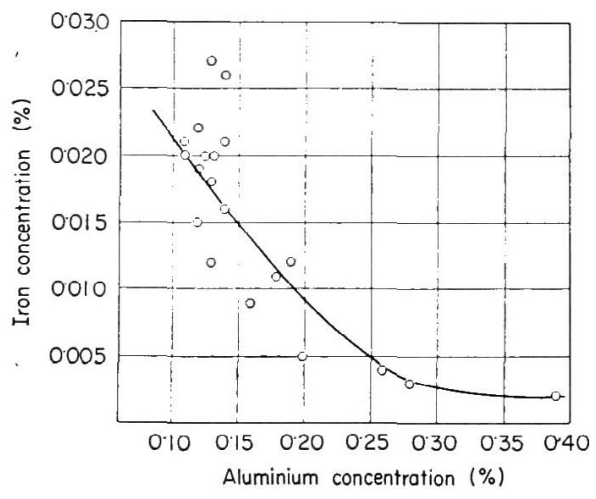

Fig. 2. Results of spectroscopic analysis of the bath in the portion free from dross suspensions.

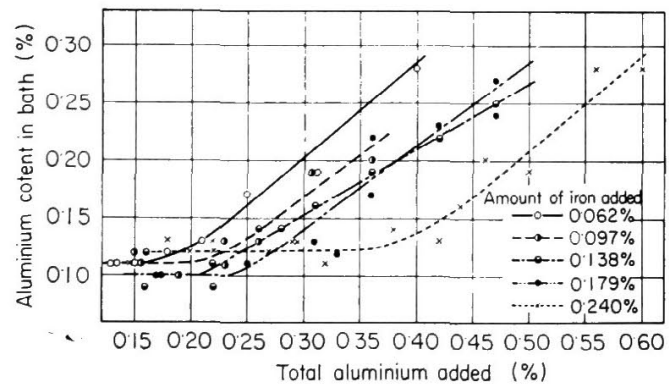

Fig. 3. Variation of aluminium content in bath with amount of iron and aluminium added.
一すなわち $465^{\circ} \mathrm{C}$ の $\mathrm{Zn}$ に溶解している $\mathrm{Al}$ 濃度— との関倸它 Fig. 3 に示す. Fe 添加量によって個々の曲 線の位置は異なるが, 全 $\mathrm{Al}$ 濃度の低い側で水平部分を もち，全 $\mathrm{A} 1$ 濃度の高い側で立ち上る直線となることは 共通である。

\section{2 ドロスについて}

実験によって得られたドロスの組織の例を Photo. 3〜 5 に示す. Photo. 3 に示したものはトップトロスで, 点 々と灰色に見えるのが $\mathrm{Fe}_{2} \mathrm{Al}_{5}$ 相である. Photo. 4 も同 様トップドロスとして観察されたものであるが，この場 合は $\delta$ 相と $\mathrm{Fe}_{2} \mathrm{Al}_{5}$ 相とが混在している. 実操業におけ るトップドロス例として示した Photo. 2 もこの種のも

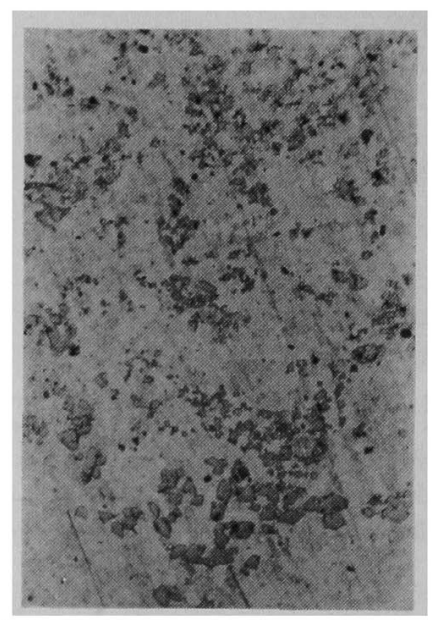

Photo. 3. Top dross formed in the present work. Compounds are $\mathrm{Fe}_{2} \mathrm{Al}_{5}$. $(\times 100)(4 / 5)$

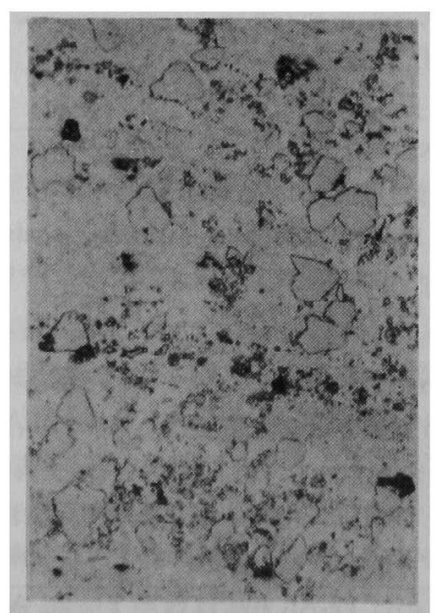

Photo. 4. Top dross formed in the present work. Compounds are $\delta$ and $\mathrm{Fe}_{2} \mathrm{Al}_{5}$.

$(\times 100)(4 / 5)$ 


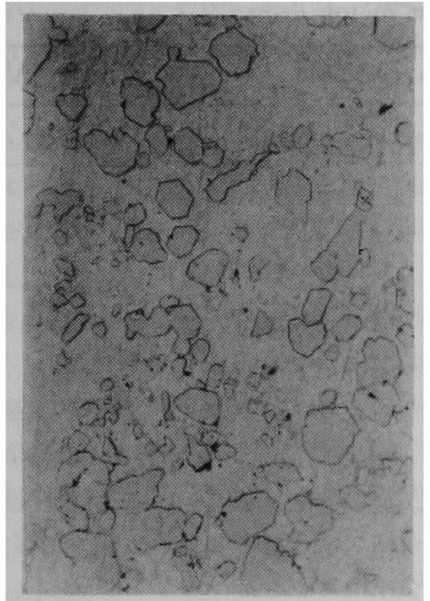

Photo. 5. Bottom dross formed in the present work. Compounds are $\delta . \quad(\times 100)(4 / 5)$

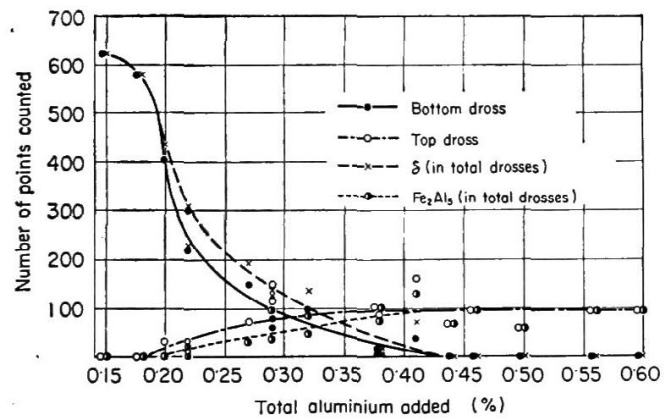

Fig. 4. Number of points counted in quantitative microscopy of dross compounds. Amount of iron added : $0 \cdot 240 \%$.

Dである. Photo. 5 はボトムドロスで， 6 角形の $\delta$ 相が 点在している.

定量組織学 : 顕微鏡視野内の格子点とドロスを構成す る金属間化合物像とが重なつた個数を計測した. Fig. 4 む $\mathrm{Fe}$ 添加濃度 $0.24 \%$ の場合の例で, 計測点数を全 $\mathrm{Al}$ 農度に対してプロットしてある. 試料底部で計測された 匕合物数（ボトムドロスの量に対応する）は全ドロス中 D $\delta$ 相計測数に，また試料上端部で計測された化合物数 トップドロスの量に対応する) は $\mathrm{Fe}_{2} \mathrm{Al}_{5}$ 相の計測数に 乩よそ対応することが見られる.しかし全 $\mathrm{Al}$ 濃度が 0.2 \% 0.4\%の間ではそれぞれの曲線は互いに一致はしな 、これはトップドロスとボトムドロスが共存する場合 こは Photo. 4 に示したように，ô相がトッブドロス中 こも，また $\mathrm{Fe}_{2} \mathrm{Al}_{5}$ 相がボトムドロス中にも観察される 䅡向があるためである. とくに $\delta$ 相はトップドロス中に Aなり多量に存在する場合があるがここれは $\delta$ 相中に Al

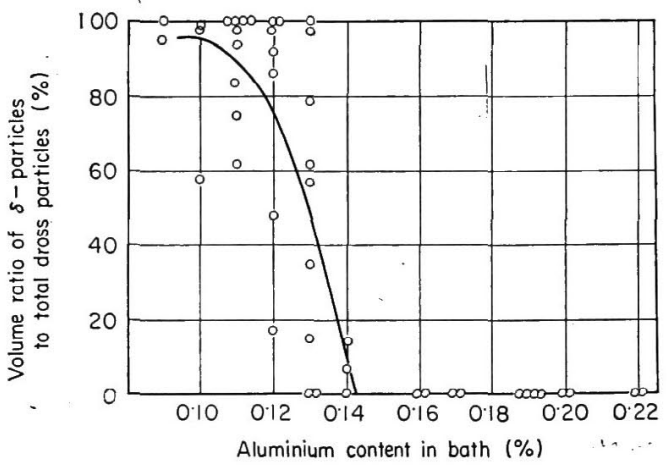

Fig. 5. Relation between aluminium content in bath and volume ratio of $\delta$-particles to total dross particles.

が相当量固溶されて比重が軽くなり上に浮んだものとも 考光られる.

全 $\mathrm{Al}$ 濃度と全 $\mathrm{Fe}$ 濃度とを種々組合わせて行なつた 実験試料について，格子点と重なつた $\delta$ 相と $\mathrm{Fe}_{2} \mathrm{Al}_{5}$ 相 の数を計測し, 両化合物のうちの $\delta$ 相の割合 (体積比率) を求めた. この割合と $\mathrm{Fe}$ 添加後の， $465^{\circ} \mathrm{C}$ でドロスと 平衡する溶融 Zn 中の $\mathrm{Al}$ 濃度との関係を Fig. 5 に示 す.ばらつきは多いが図にみるように，Zn 中の Al 濃 度の増加とともに $\delta$ 相の比率は減少し, $\mathrm{Al}$ 濃度が $0.15 \%$ 以上の場合は $\delta$ 相はないことがわかる.なお図中の実線 は回帰線をあらわしている.

\section{3 トップドロスのX線回折結果}

§2 に記したように，トップドロスの主体をなす金属 間化合物が $\mathrm{Fe}_{2} \mathrm{Al}_{5}$ 相であるとすることには異なつた見 解もあるので，この点を確認するためX線回折により検 討した.

実操業で生成したトップドロスを黒鉛ルツボ中で再融 解して化合物をさらに浮上させ，化合物が濃縮している インゴット上部から試料を切り出した・ターゲットは $\mathrm{Fe}$ を使用し, 回折角 $2 \theta$ は $10^{\circ} \sim 70^{\circ}$ の範囲とした. 得ら れた結果をまとめて Table 1 に示す. 表に見るようにト ップドロス中のおもな金属間化合物は $\mathrm{Fe}_{2} \mathrm{Al}_{5}$ 相11)であ る.

\section{5. 実操業と実験結果との関係づけ}

\section{1 実操業におけるドロス生成量の推算}

浴が Fe で飽和している実操業において，ドロスは主 として鋼板から溶出した Fe との反応で生成すると考え， 前報 ${ }^{2)}$ の万法で求めた $\mathrm{Fe}$ 溶出量からドロス生成量を推 算することとした.

ドロス生成量はボトムドロスとトップドロスとにつき 
Table 1. Identification of phases present in top dross.

\begin{tabular}{|c|c|c|c|c|c|c|c|}
\hline \multicolumn{2}{|c|}{ Observed } & \multicolumn{2}{|c|}{$\mathrm{Fe}_{2} \mathrm{Al}_{5} \quad(\mathrm{ASTM})$} & \multicolumn{2}{|c|}{$\mathrm{Zn}$ (ASTM) } & \multicolumn{2}{|c|}{$\mathrm{FeZn}_{7}(\mathrm{ASTM})$} \\
\hline $\mathrm{d} \AA$ & I obs. & $\mathrm{d} \AA$ & $\mathrm{I} / \mathrm{I}_{1}$ & $\mathrm{~d} \AA$ & $\mathrm{I} / \mathrm{I}_{1}$ & $\mathrm{~d} \AA \AA$ & $\mathrm{I} / \mathrm{I}_{1}$ \\
\hline $\begin{array}{c}3 \cdot 79 \\
3 \cdot 20 \\
2 \cdot 71 \\
2 \cdot 46 \\
2 \cdot 36 \\
2 \cdot 30 \\
- \\
2 \cdot 15 \\
2 \cdot 12 \\
2 \cdot 09 \\
2 \cdot 06 \\
- \\
1 \cdot 68\end{array}$ & $\begin{array}{l}\text { VW } \\
\text { VW } \\
\text { VW } \\
\text { VS } \\
\text { VW } \\
\text { S } \\
\overline{V W} \\
\text { W } \\
S \\
W \\
- \\
\text { m }\end{array}$ & $\begin{array}{l}2 \cdot 11 \\
2 \cdot 05 \\
1 \cdot 94 \\
1 \cdot 90\end{array}$ & $\begin{array}{r}100 \\
100 \\
10 \\
8\end{array}$ & $\begin{array}{l}2 \cdot 47 \\
2 \cdot 31\end{array}$ & $\begin{array}{l}53 \\
40\end{array}$ & $\begin{array}{l}2 \cdot 23 \\
2 \cdot 14\end{array}$ & $\begin{array}{r}90 \\
100\end{array}$ \\
\hline
\end{tabular}

别個に求めなければならない，そこでまず溶出 $\mathrm{Fe}$ がボ トムドロスとトップドロスにどのような比率で分配され るかを考察する．例として顕微鏡視野内の格子点と重な

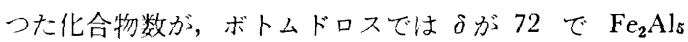
が4, トッブドロスでは $\delta$ が 7 で $\mathrm{Fe}_{2} \mathrm{Al}_{5}$ が 84 である 実験絬果を想定する.これらの数值はその絶対值は不明 であるが前述したように体積比率に相当するので， $\delta$ 相 と $\mathrm{Fe}_{2} \mathrm{Al}_{5}$ 相との密度である $7 \cdot 24$ と $4 \cdot 2$ とを用いて, まず重量比率に換算する，上記例ではボトムドロス中の $\delta$ は $10, \mathrm{Fe}_{2} \mathrm{Al}_{5}$ は1, トップドロス中の $\delta$ は $1, \mathrm{Fe}_{2} \mathrm{Al}_{5}$ は20 の比率となる. 一方前記したように $\delta$ 相中の $\mathrm{Fe}$ 濃度は $10 \%, \mathrm{Fe}_{2} \mathrm{Al}_{5}$ 相中の $\mathrm{Fe}$ 濃度は $45 \%$ と 3 元状態 网から読みとれる。したがってボトムドロス中の Fe は $\delta$ として 1·0, $\mathrm{Fe}_{2} \mathrm{Al}_{5}$ として 0.45, トップドロス中の $\mathrm{Fe}$ は $\delta$ として $0 \cdot 1, \mathrm{Fe}_{2} \mathrm{Al}_{5}$ として $9 \cdot 0$ 含まれている ことになる.したがってこの例の場合の溶出 Fe がボト ムドロスとなる割合 $r_{B}$ は,

$$
r_{\mathrm{B}}=(1 \cdot 0+0 \cdot 45) /(1 \cdot 0+0 \cdot 45+0 \cdot 1+9 \cdot 0)=0 \cdot 14
$$

溶出 $\mathrm{Fe}$ がトップドロスとなる敖合 $r_{\mathrm{T}}$ は

$$
r_{\mathrm{T}}=1-r_{\mathrm{B}}=0.86
$$

となる・格子点測定の実駼絬果を上述のように変捘して 横㠹に溶融 $\mathrm{Zn}$ 中の $\mathrm{Al}$ 濃度, 縦呐に $r_{\mathrm{B}}$ をとると Fig. 6 を得る。図中の実線は回帰線である.

$r_{B}$ と $r_{\mathrm{T}}$ の值と $\mathrm{Fe}$ 溶出量 $\Delta W_{1}\left(\mathrm{~g} / \mathrm{m}^{2}\right)$ およびボトム ドロスとトップドロス中の $\mathrm{Fe}$ 漉度 $\mathrm{Fe}(\mathrm{B}) \%, \mathrm{Fe}(\mathrm{T}) \%$ とを用いれば，Zn 単位使用量当たりのドロス量は次式 で推算できる*.

$$
\begin{aligned}
& \text { ボトムドロス量 } B: \\
& \quad B=200 \cdot J W_{1} \cdot r_{\mathrm{B}} / \mathrm{Fe}(B) \cdot w \\
& \text { トップドロス量 } T:
\end{aligned}
$$

$$
T=200 \cdot J W_{1} \cdot r_{\mathrm{T}} / \mathrm{Fe}(T) \cdot w
$$
全ドロス蕁 $D$ :

$$
D=B+T
$$

ただしいは亜鉛付着量（ $\mathrm{g} / \mathrm{m}^{2}$-sheet）である.

というのは，Zn 単位使用量当たりに溶出した Fe 量は $2 J W_{1} / w$ で表わされるから，ボトムドロス中の $\mathrm{Fe} \cdot$ 量 は $2 J W_{1} \cdot r_{\mathrm{B}} / w$ である.このボトムドロス中の $\mathrm{Fe}$ 濃度 が $\mathrm{Fe}(\mathrm{B}) \%$ であるから，（1)式によってボトムドロス 量が求められることになる.

つぎに（1）（2）（3）式を用いて代表的な条件のも とでのドロス生成量を推算する. $\mathrm{Fe}(B)$ および $\mathrm{Fe}(T)$

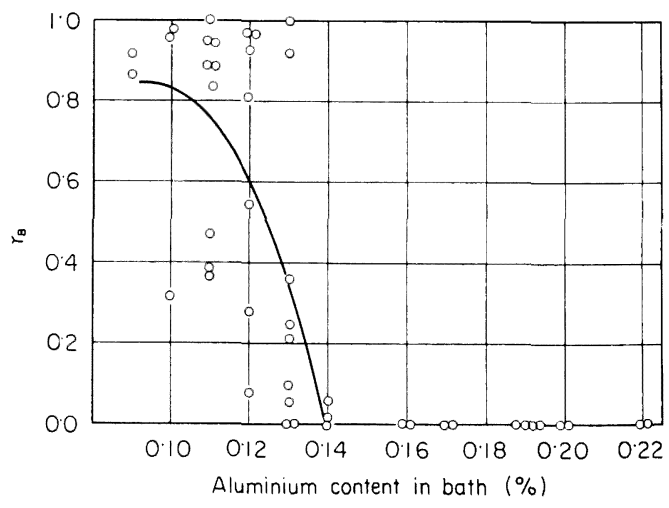

Fig. 6. Relation between aluminium content in bath and $r_{\mathrm{B}}$ (calculated). $r_{\mathrm{B}}$ : Ratio of iron in bottom dross to total iron dissolved.

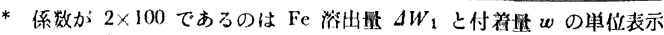

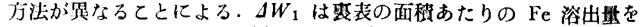

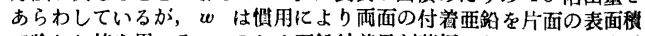

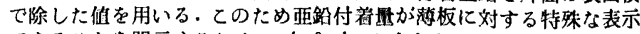
であることを明示するため, $\mathrm{g} / \mathrm{m}^{2}$-sheet とした。
} 
むFig. 1 からそれぞれ $4.0 \%$ および $2.0 \%$ とし， ま そいは $275 \mathrm{~g} / \mathrm{m}^{2}-$ sheet $\left(0.90 \mathrm{z} / \mathrm{ft}^{2}\right.$-sheet) を代竖条件と してえらぶ. $\Delta W_{1}$ は前報2) の (1) 式より, ラインス ピード $80 \mathrm{~m} / \mathrm{min}$, 鋼板の温度 $470^{\circ} \mathrm{C}$ の条件を代入して 容融 $\mathrm{Zn}$ 中の $\mathrm{Al}$ 濃度 $0.10 \sim 0.20 \%$ について求め, 0.50 一 $0.25 \mathrm{~g} / \mathrm{m}^{2}$ を得た， $r_{\mathrm{B}}$ を Fig. 6 から読みとり， $r_{\mathrm{T}}$ を 求めた. 以上の数値を（1）（2）（3）式に代入して計 算した結果 Fig. 7 を得た。図における溶融 $\mathrm{Zn}$ 中の $\mathrm{Al}$ 農度変化にともなうドロ 又生成量の変化は, $\mathrm{Al}$ 浱度 0.14 $\%$ 以下の場合は $r_{\mathrm{B}}$ と $r_{\mathrm{T}}$ の变化に依存しており, $0 \cdot 15 \%$ $\mathrm{Al}$ 以上の場合は Fe 溶出量の变化に依存している.

なお実操業の場合，ボトムドロスの生成量が多いこと ま，これを除去するためラインをとめてかきだすという 手間を要し，またメッキ板に粗大な $\delta$ 相化合物が付着し てメッキ板の外観不良を招くことからとくにきらわれ $3^{12)}$. この点から Al 濃度を高めてボトムドロスの生成 をおさえることは操業上重要である.

なお以上の推算は溶出 $\mathrm{Fe}$ がすべてドロスとなつて残 ることを仮定している。しかし実操業ではメッキ板に付 着して系外に出る微細な Fe 化合物も無視できないので， 及み出すべきドロス量は上記推算量より小上なることも 考えられる、またラインスピードを增すと酸化物のまき こみが増加して, トップドロス量は増加する傾向がある

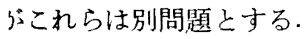

\section{i.2 ドロス生成のための浴中 Al の消費量について}

本ルツボ実験では Fe を母合金の形で添加してドロス 生成させたが，実操業においてはドロス生成は鋼板か うの Fe 溶出に起因している，ドロス生成の際には， $\mathrm{Fe}$ 対してある比率をもつて Al が消費されて化合物を生

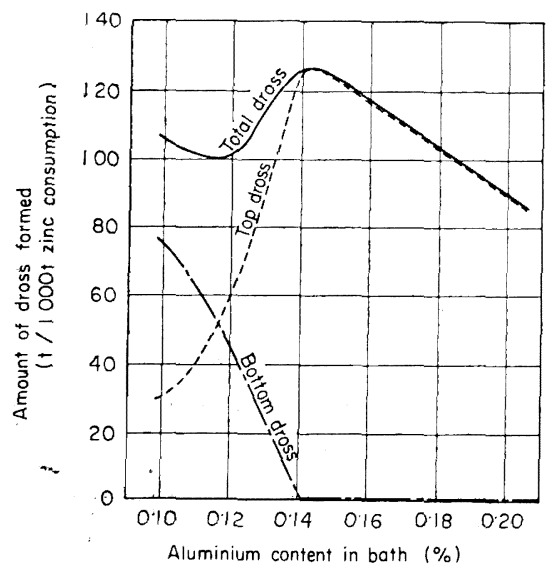

Fig. 7. Estimated amount of drosses in relation to $\mathrm{Al}$ content in bath.
成与る.この $\mathrm{Al}$ の消費のための实操業において・メッ キ浴中の $\mathrm{Al}$ 裖度，一一通常このような表現をとるが，そ の意味は溶融 Zn 中に溶解している $\mathrm{Al}$ の濃度である を任意の水準に管理することが困難な問題となつてい る. 浴中の $\mathrm{Al}$ 濃度の管理方法に関しては次報で検討す るが，ここではこのような解析を可能とするため，ド口 ス生成の際に消費される浴中の $\mathrm{Al}$ 濃度に関して検討与 る.

Fig. 3 にみるようなわれわれのルツボ実験の結果は， 全 $\mathrm{Al}$ 濃度が $z(\%)$ のきこれに全濃度こして $x^{\prime}(\%)$ の $\mathrm{Fe}$ をくわえると，ドロスを含まない浴（溶融 $\mathrm{Zn}$ ) 中の $\mathrm{Al}$ 濃度が $y \%$ になることを示している。この結果を用 いて，実操業に則した Fe 溶出にともなうドロス生成と 浴中 $\mathrm{Al}$ 濃度との関係式を導きたい。

まず，Fe を饱和している実操業の条件に対応させて， $\mathrm{Fe}$ の添加量として全 $\mathrm{Fe}$ 濃度 $x^{\prime}$ から浴. (溶融 $\mathrm{Zn}$ ) 中 の $\mathrm{Fe}$ 飽和濃度をさし引いた値 $x(\%)$ を用いる。 $x=x^{\prime}-(\mathrm{Fe}$ 飽和濃度 $)$

$\mathrm{Fe}$ 飽和濃度としては Fig. 2 の曲線から読みとつた值を 用いたささらに全 $\mathrm{Al}$ 濃度 $(z \%)$ と $y, x$ と間の閔係と してつぎの一次式を仮定した：

$$
y=\mathrm{l}-\mathrm{m} x+\mathrm{n} z
$$

(5)式を用いて実験結果の整理を行なうが，その際実 験值 $y, x, z$ がそれぞれ実操業における種々の数值と どのように対応するかの検討が必要である．まず過飽和 に添加された $\mathrm{Fe} x \%$ は，片面の面皘 $S\left(\mathrm{~m}^{2}\right)$ の鋼板を メッキする間にメッキ槽中の $M(\mathrm{~g})$ の $\mathrm{Fe}$ 飽和浴中に 溶出 ${ }^{2)}$ する $\mathrm{Fe}$ 量, $2 \Delta W_{1} \cdot S(\mathrm{~g})$ ，の濃度 $(\%)$ 表示に対 応するから

$$
x=200 S \cdot \Delta W_{1} / M
$$

また，全 $\mathrm{Al}$ 濃度こはわれわれのルツボ実験において は過剩の $\mathrm{Fe}$ を加えてのちは，ドロス中の $\mathrm{Al}$ 量とドロ スを含まない溶融 $\mathrm{Zn}$ 中に溶解している $\mathrm{Al}$ 量との和の 濃度であるから， $\mathrm{Fe}$ 飽和条件での実操業ではつぎのよ うになる.すなわち, 全 $\mathrm{Al}$ 濃度 $z$ は片面の面積 $S$ の鋼 板をメッキする間に，浴の補充のために新たに槽中に入 る $(\mathrm{Zn}$ 合金中の) $\mathrm{Al}$ 量とメッキ板に付着して系外に持 ち出される $\mathrm{Al}$ 量との差（ドロス生成についやされる $\mathrm{Al}$

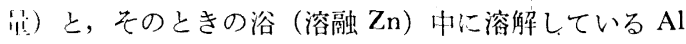
黾との和の濃度表示である。したがって，浴の重量に増 減がなく浴の補給が連続的に行なわれるものとみなし $\tau$,

$$
z=\left(y_{\mathrm{T}}-Y\right) w S / M+y
$$

ここに， $y_{\mathrm{T}}$ ：メッキ浴補給に用いる Zn 合金（Tailored Zinc) 巾の $\mathrm{Al}$ 濃度 $(\%)$ 
$Y:$ 合金層を含むメッキ層中の $\mathrm{Al}$ 濃度 $(\%)$ なお，浴中の $\mathrm{Al}$ 濃度 $y$ の意味は前述のようであるが, 実操業中の溶融浴の採取分析值は，金属間化合物の分巏 が不十分のためであろう，われわれの実験值より高く求 められるのが一般のようである.

さて, 式（6)，（7）を式（5）に代入して（8）式 を得る：

$$
\{(1-\mathrm{n}) y-1\} M / w S=\mathrm{n}\left(y_{\mathrm{T}}-Y\right)-200 \mathrm{~m} \cdot \Delta W_{1} / w
$$

鋼板面積 $S$ のいかんにかかわらず（8）式が成立するた めには

$$
\begin{aligned}
& y=1 /(1-\mathrm{n}) \\
& y_{\mathrm{T}}-Y=200 \mathrm{~m} \cdot \Delta W_{1} / \mathrm{n} w
\end{aligned}
$$

が同時に成立しなければならない，すなわち，メッキ浴 中の $\mathrm{Al}$ 濃度がちがえば（10) 式の $\Delta W_{1}$ の係数は異な るはずである。

実験結果の整理は上記考察にもとづき，個々の浴 $\mathrm{Al}$ 濃度值 $y$ ごとに（5）式の回帰方程式を求めた。この回 帰方程式を求める際に用いたデータは，ある浴 $\mathrm{Al}$ 濃度 $y$ およびこれと $\pm 0.01 \%$ の範囲で異なる濃度の場合の すべての $x, z, y$ の組合わせの数值とした． 回帰方程 式から得られた（5）式の係数 $1, \mathrm{~m}, \mathrm{n}$ の值を，(9) 式と（10）式に代入して横軸に $1 /(1-n)$, 縦軸に $\mathrm{m} / \mathrm{n}$ をとつた図が Fig. 8 である。

(10) 式は実操業における物質収支式であると考えら れ，したがってつぎのような解勫ができる.すなわち， 入出差 $\left(y_{\mathrm{T}}-Y\right)$ はドロス生成のために消費される $\mathrm{Al}$ 濃度に相当するので， $w\left(\mathrm{~g} / \mathrm{m}^{2}\right.$-sheet $)$ の $\mathrm{Zn}$ 合金を補 給すると $\left(2 \Delta W_{1} \cdot \mathrm{m} / \mathrm{n}\right)$ の $\mathrm{Al}$ がドロス生成のためにつ いやされることがわかる. 一方この間に $2 \Delta W_{1}$ の $\mathrm{Fe}$ が

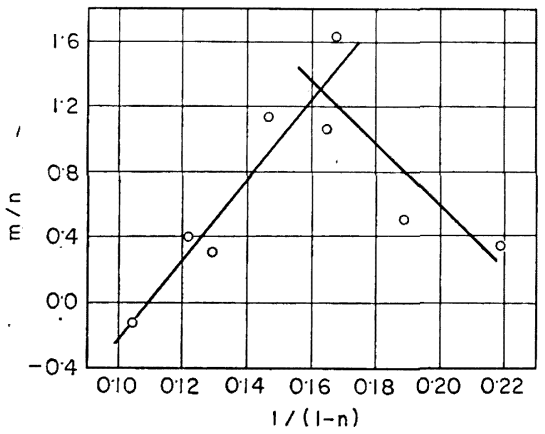

Fig. 8. Plot of $m / n$ vs. $1 /(1-n)$. $m / n$ corresponds to concentration ratio of $\mathrm{Al} / \mathrm{Fe}$ in total dross. $1 /(1-n)$ corresponds to aluminium content in bath.
浴中に溶出されているので，ボトムドロスとトップドロ スとをあわせた全ドロス中の $\mathrm{Al}$ 量と $\mathrm{Fe}$ 量との比, $\mathrm{Al}$ / Fe, は $\mathrm{m} / \mathrm{n}$ となる. このようにして Fig. 8 はメッキ 浴中の $\mathrm{Al}$ 濃度 (横軸) と全ドロス中の $\mathrm{Al} / \mathrm{Fe}$ 比（縦 軸）との関係を示す図であるとみなせる.

\section{6. 考察}

Fig. 3 の各曲線は水平部とこれから立ち上つた勾配を もつ直線部とからなつている.この 2 直線からなるとい う傾向は相律によって説明が可能である. すなわちこの 系は $\mathrm{Zn}, \mathrm{Fe}, \mathrm{Al}$ の 3 成分からなつているとみなせるの で, $\delta$ 相, $\mathrm{Fe}_{2} \mathrm{Al}_{5}$ 相, 融液相の 3 相が共存する場合は, 温度がきまると自由度がなくなり, 融液中の $\mathrm{Al}$ 濃度は かわりえないので直線は水平となる，一方 $\mathrm{Fe}_{2} \mathrm{Al}_{5}$ 相, 融液相の 2 相からなる場合は自由度は 1 となり, 融液中 $\mathrm{Al}$ 濃度は全 $\mathrm{Al}$ 濃度により变化して立ち上つた直線とな る.

前節で検討したように Fig. 8 は浴中の $\mathrm{Al}$ 濃度と全ド ロス中の $\mathrm{Al} / \mathrm{Fe}$ 比との関係を示しているとみなせる. 一方ドロスを構成する金属間化合物中の $\mathrm{Al} / \mathrm{Fe}$ 比は $\S 2$ で検討したように， $\delta$ 相で $0 \cdot 3, \mathrm{Fe}_{2} \mathrm{Al}_{5}$ 相で $1 \cdot 0$ と推 定される. したがって Fig. 8 における $\mathrm{m} / \mathrm{n}$ は, 浴中の $\mathrm{Al}$ 濃度が増すにつれドロスを構成する両金属間化合物 中の $\mathrm{Fe}_{2} \mathrm{Al}_{5}$ の比率が増すので, 0.3 から 1.0 まで増加 して, 浴中の $\mathrm{Al}$ 濃度が $0.15 \%$ 以上となり化合物相が $\mathrm{Fe}_{2} \mathrm{Al}_{5}$ のみになると 1 の值で一定となると予想される. しかし Fig. 8 によれば， $\mathrm{Al}$ 濃度が低い場合（〜0.10\% $\mathrm{Al})$ と高い場合（〜0.2\% Al） とはこの予想からはずれ る.このことに関する検討は今後の問題として残す.

次報においてわれわれはメッキ浴補給に用いる $\mathrm{Zn}$ 合 金に最適な $\mathrm{Al}$ 含有量を推算したい.そのために,ドロス 生成反応によつて消費される $\mathrm{Al}$ 量を推定する必要があ る.5.8 に記したように全ドロス中の $\mathrm{Al}$ 量と $\mathrm{Fe}$ 量との 比, $\mathrm{Al} / \mathrm{Fe}$, $\mathrm{m} / \mathrm{n}$ となる.一方実操業において,ドロス は主として鋼板から溶出した $\mathrm{Fe}$ との反応で生成すると 考えるので，溶出した $\mathrm{Fe}$ 量を $\Delta W_{1}\left(\mathrm{~g} / \mathrm{m}^{2}\right)$ とすると， ドロス生成のために消費される $\mathrm{Al}$ 量は $\Delta W_{1} \cdot \mathrm{m} / \mathrm{n}$ $\left(\mathrm{g} / \mathrm{m}^{2}\right)$ であらわされる. m/n は, Fig. 8 から浴中 $\mathrm{Al}$ 濃度が $0.12 \%$ から $0.15 \%$ に増加するにしたがって, 0.24 から 0.99 に増加するという結果を得た. 以上の ようにしてドロス生成反応による $\mathrm{Al}$ 消費量を実験值で ある $\left.\Delta W_{1}^{2}{ }^{2}\right)$ と $\mathrm{m} / \mathrm{n}$ とによつて推算することができる.

\section{7. 結}

論

（1）連続溶融覀鉛メッキにおけるドロス中の 金属間 
化合物は， $\delta$ と $\mathrm{Fe}_{2} \mathrm{Al}_{5}$ とからなつている. $\delta$ はメッキ 浴底部にしずみボトムドロスとなり, $\mathrm{Fe}_{2} \mathrm{Al}_{5}$ は上部にう かびトップドロスとなる傾向が大きい.

(2) $465^{\circ} \mathrm{C}$ のメッキ浴中の $\mathrm{Al}$ 濃度（溶融 $\mathrm{Zn}$ に 溶解している Al の濃度）が 0.09〜0.14\% の籁囲では $\delta$ と $\mathrm{Fe}_{2} \mathrm{Al}_{5}$ が共存するが, $\mathrm{Al}$ 浱度が上るにつれ, $\mathrm{Fe}_{2} \mathrm{Al}_{5}$ の比率が増加する. $\mathrm{Al}$ 濃度が $0 \cdot 15 \%$ 以上の場合には $\delta$ は存在しない.

（3）ボトムドロス生成量は浴中の $\mathrm{Al}$ 濃度が 0.09 〜 $0.14 \%$ の範囲では $\mathrm{Al}$ 濃度が増すに従つて減少し, $0 \cdot 15 \% \mathrm{Al}$ 以上となると生成しないことが推算された. トップドロス生成量は逆に浴中 $\mathrm{Al}$ 濃度の增加にしたが って増加するが，0.15\% A $\mathrm{Al}$ 以上となると Fe 溶出吊の 減少のため生成量は漸減する.

最後にこの研究の進行にあたり, 三井金属中研の諸氏 に種々のご援助をいただいたことを感謝します。また熱 心に実験に協力された小林秀年, 田中国教, 内堀豊一の 三氏に謝意を表します。

1) 山口, 久松: 鉄と鋼, 59 (1973), p. 131
2) 山口. 久松: 鉄と鋼, 59 (1973) p. 1994

3 ) E. H. Rennhack: Trans AIME, 221 (1961), p. 775

4) W. Köster and T. Gödecke: Proc. 9th Int. Conf. on Hot Dip Galvanizing (ZDA), (1971), 128 [Industrial Newspapers Ltd.]

5 ) D. I. Cameron and $M . K$. Ormay: Proc. 6th Int. Conf. on Hot Dip Galvanizing (ZDA), (1962), 276 [Industrial Newspapers Ltd.]

6) H. BABLIK: Galvanizing, (1950), p. 164, [E \& F. N. SPON Ltd.]

7 ) A. R. Borizillo and $W . C$. HAHN Jr: Trans. ASM, 62 (1969), p. 729

8) $R$. R. Miller: Liquid-Metals Handbook (Atomic Energy Commission), (1952), p. 41

9 ) J. E. Hilliard: Quantitative Microscopy (ed. by $R$. T. Dehoff, $F$. N. Rhines), (1968), p. 45 [McGraw-Hill Book Company]

10) D. C. Pearce: Effect of Aluminium on Galvanized Coatings Produced from Iron-Saturated Spelter, (1970), [ASARCO]

11) D. Horstmann: Arch. Eisenhüttenw., 27 (1956), p. 297

12）鮎沢，安藤，岩崎，村上：公開特許公報 47-38630 